\title{
The Method of Teenager Legal Education from the Perspective of the Rule of Law
}

\author{
Liang Sun \\ Department of Ideological and Political Theory,Agricultural University of Hebei,Baoding,China
}

\begin{abstract}
The society has been full of all kinds of thoughts in people's daily life since the reform and opening up policy be carried out. The teenagers, in physiological and psychological growth stage, will be affected by various social bad thoughts and behavior easily. Because the school education of legal system is not perfect and the legal education in the family is lacking. It will produce illegal behavior and criminal acts. There is a simple analysis for the influence for legal education produced by society, school and family. And we will put forward the corresponding countermeasures to strengthen legal education for teenagers, to improve the legal consciousness and avoid illegal and criminal behavior.
\end{abstract}

Keywords: the teenager; legal education; method

\section{INTRODUCTION}

"According to statistics released by the National Bureau of Statistics, in the people's court accepted the case in 2002, the number of young offenders is 217909. Accounted for $31 \%$ of the total number of criminals, in 2007 it is 316298 , accounted for $33.9 \%$ of the total number in $2007 . "{ }^{[1]}$ It is related to the age, the ability to distinguish right from wrong and the social experience admittedly, a portion of teenagers do not study the law seriously, the legal concept of law is not enough and low law quality are also important reasons for this. At the same time, we should find that the contents of legal education in schools lack of specific in the exam oriented education system, and the legal system education is treated as a decorative work, so it leaves everything to the enrollment rate. However, in the new situation of the rule of law, as the method of developing a correct outlook on life and values, improving the legal literacy of teenagers, the legal education get more and more attention by the party and the country.

\section{The importance of strengthening teenagers' education in legality}

\section{1. improving the teenagers' law attainment, guiding them abide by the law consciously}

Teenagers are the future and hope of our country, the teenagers' crime rate remains high in recent years, it has a great effects on the future of our modernization construction, so paying more attention to the legal education of young people, improving the legal literacy and guiding the conscious are the serious work for prevention of teenager's crime. In the implementation process of teenager's legal education, organizing special activities may help them understand the operation mode of the law, feel the value of the pursuit of justice and establish the correct values, such as auditing court case hearing process, analyzing special case and learning the spirit of constitution. In addition, by experiencing the serious harm of some illegal cases, understand the punishment with strict laws, it can set up the dignity of the law, so that young people have a common faith in the law of our country, restrain the illegal crime psychology of adolescent and guide the young people abide by the law consciously. "To improve the Law quality of juvenile is the key to improve the quality of the whole nation. we must take the law education for teenagers on the basis of status related to the realization of China's socialist modernization construction, and put it in an important position of our education, make it become an urgent task, be implemented carefully. "[2] 


\subsection{Promoting the strategy of ruling by law in China more comprehensive}

Implementing the strategy of governing the country by law is the inherent requirement of building a socialist country ruled by law, "improving legal education, enhancing citizens' legal consciousness and concept is the foundation of engineering construction of socialist legal system, and it is also the important content of strengthening the construction of socialist spiritual civilization." ${ }^{[3]}$ Teenagers is an important target of China's legal education, to realize the rule of law, the country strategy, we must strengthen legal education for the juvenile except for maintaining the dignity of legislation, law enforcement. Only improve the teenagers' knowledge of the law and the law literacy can ensure he make a beneficial effects the when he go to work .The eighteen Party's report has clearly pointed out that "we should advance the in-depth development of legal publicity and education, carry forward the spirit of socialist legal system, establish the socialist concept of rule of law, enhance the whole social learning law abiding consciousness". Although we have entered a new period of socialist construction, the citizens' qualities of legal knowledge still inadequate due to some negative effects of history and performance. These will become the obstacles of ideas of rule of law. To establish atmosphere that the supremacy of law and accordance with the law are inseparable from the legal education. The young people is the motherland successor, is the backbone of the building of socialist countries, their legal concept of high or low plays a fundamental role in promoting the process of China's rule of law.

\section{The problem and deficiency of legal education}

\subsection{The problems and shortcomings of the legal education in school}

\subsubsection{Emphasizing the exam oriented education on one-sided and ignoring legal education}

Emphasizing the exam oriented education on one-sided and ignoring legal education is the first reason. As the cradle of growing young people, the school is an important base that they learn scientific knowledge, The young students spend most of their time in school, school education is has a very important influence for teenagers. They not only study the basic scientific and cultural knowledge that the state requires, but also learn some education courses that help them form a complete personality quality, such as courses related to ideological and moral course, manual labor course and legal education. Those courses is to help them learn something beyond the book, set up perfect personality. At present although our country has repeatedly stressed the importance of quality education, and constantly asked schools to the content of quality education curriculum into your daily life and study, make the content of quality education plays the role of influence character by environment in students' daily life, such as the ideological and moral and legal education, need students to achieve the internal transformation based on cognition and understanding, which require the student study it and realize it, final out of their actual behavior. But in the pursuit of high rate and other reasons, the current school education in our country still stays in the surface layer of the exam oriented education, Chinese, mathematics, and English these major curriculum pursuit of senior high school entrance examination and college entrance examination requirements, this kind of course timetabling arrangements in quantity, quality of the arrangement of the full-time teachers is also high, therefore received more good teaching effect. Because of this the wrong target, there are a lot of problems in both the management and teaching activities. It leads the legal education becomes a mere formality.

\subsubsection{There is no scientific system of legal education.}

There is no scientific system of legal education. The students in school are teenager's mainstream groups, so the school is the main position for teenagers' legal education activities. But because of the influence of the exam oriented education system, legal education of young people in the school has not received enough attention. Because of the lack of understanding of legal education in school, some school think that legal education is to carry out a number of 
legal thought of lectures, or please some court for teenagers to talk briefly about the national laws and policies, there is no need to occupy special classroom time to teach legal knowledge for teenagers. So the youth legal education in school education system is not perfect. Firstly, legal education course lacks the powerful safeguard in the course settings, some schools even have not set up the specialized legal system education, nor put the legal education teaching plan into the whole teaching plan. Only carrying out a general class or school lectures popularizing all the students occasionally during the semester. They have not conduct the national legal knowledge in-depth explanation by the small class teaching perspective, if we cannot propaganda the legal knowledge to students in the actual teaching contents, we will lose a lot of useful information about the teenagers' real thought for legal, a wide range of educational communication way is not in-depth understanding of the legal quality for each student, so the teacher cannot put forward specific opinions according to the existing situation. In the teaching staff, there is no strict requirements for the teacher who teaching legal education. Most teachers who teach the legal education courses are mostly part-time by teachers of ideological and political education in a lot of school in our country at present. Although there are certain legal general knowledge in ideological and political education course in middle school, but this is not a complete system of legal education, but the fragmented knowledge that cannot make up a comprehensive design. Coupled with the ideological and political education teachers pay more attention to the education of students' ideology and morality from the professional point of their own view and create, their legal literacy may not be very complete, so it is more difficult for them to teach the students learn the complicated legal framework. Secondly, content of legal education is differentiation, teaching form is single and boring. The contents of legal education is one of the core issues of legal education, compared with other courses, legal education does not have a unified standard and specification in majority of school. In addition, because of its lower status in school, the legal system education is not valued, it's teaching content also showed differentiation and discontinuity.

\subsection{The problems and shortcomings of the legal education in family}

Although with the development of social economy progress and education in the modern family, the situation that parents lack of legal knowledge and the weak sense of law is changed. They began to pay more attention in the comprehensive development of children and grow up, the older generation of parents treat the stereotyped reading as the only way to change your life, but the parent, influenced by the relevant state propaganda work, have gradually recognized that exerts significant impacts of quality education to the child in the new era, they believe that they should let the children learn extensively diverse knowledge. Although many parents have a new understanding in the quality education, there are still some parents have insufficient legal knowledge, legal consciousness and the legal concept are lack. Their understanding and view of legal is probably declinational, and has the deviation of national laws and regulations, they cannot learn and understand law in a right way, so they cannot teach the relevant legal knowledge to the children Because the parents' legal quality is not enough, they have a big difficulty when they launch the legal education for their children, even cause more serious event when they deal with the other problem in children' life.

Being indifferent to legal education is another type of ill family. Parents do not care for their child so much, which put the teenagers in a terrible runaway state. Some parents are busy with their work and ignore their children, they think that giving the children necessary material condition is enough. They do not care children' emotion need and let their thought fluctuation, this is a common problem at present of our country. The teenagers are in the stage personality character take a follow one's own inclination and attitude, which is a common problem Young people are at a special stage that all aspects are immature, if the parents ignore their psychological emotional needs, they will be affected by the harmful effect especially in the lack of family warmth and necessary discipline in the family. It 
will cause a series of serious problems. By the time children' crime event has happened, it is too late. And rough type family is very easy to arouse the children' psychological react, or make them give up on themselves, and even go to the extreme. Some parents emphasis on the authority of parents so much, treat the children' issue is a simple and rough way, require the children follow what they said without Interpretation. For children' correct behavior, they do not give the necessary encouragement, but there will be a severe punishment if the children make mistakes.

\subsection{The problems and shortcomings of the legal education in society}

The ideological culture, concept of value, life style of the western world infiltrate the teenagers in various forms at the present society, multiculturalism and various challenges or opportunities in social development makes young people have adaptability, orientation and selective difficulty. In the youth appeared confused political beliefs, value orientation, and lack of social responsibility etc... The evil social influence such as extravagance, hedonism, utilitarianism in the society make the teenagers' life corrupted, destroy their sense, weaken their mind, which is very easy to induce the problem of juvenile to the road of crime. Bad social ideological and cultural ethos has also become the legal education block to prevent teenager's healthy growth. Network information is so complicated, that teenagers can't obtain the correct information independently, when they faced with some illegal and criminal phenomenon, they will confuse right and wrong, they also can not consider the question in the legal perspective; so they may become the tool of criminals and victims, they can't use a legal weapons to protect their legitimate rights, the worst part is that some young people fall into the illegal crime abyss because of the Internet Addiction. In addition, the network construction lacks of legal management and strong supervision, the guarantee function of law is not manifested in front of teenagers, instead, the legal loopholes make some people with evil intent guide public opinion in the wrong direction behind network. It revives the teenagers' thinking, make the negative influence on personal growth and development in adolescents, it is not only unfavorable for cultivating the teenagers' legal consciousness and skills, but also run in opposite directions with youth legal education goal.

\section{The method of strengthening teenagers' legal education to carry out}

\subsection{Launching legal education with education of teenagers \\ Psychological}

The teenagers is in the formation stage of world outlook, life outlook, and values, they usually have strong desire for knowledge and is full of curiosity for the different new things, and they can discover and grasp the fresh thing, and has strong ability of imitation at the same time. For some of the negative even crime news on the Internet, sometimes, they do not have the ability to judge the value of it, so some lawless elements use the humbug or lie to seduce the teenagers do something break the law. These problems is closely related to the physical and psychological characteristics of adolescents, therefore, when we carry out legal education, we need to start from the teenagers' psychological characteristics. On the one hand, we can timely discover some undesirable tendency that may have appeared, for example, many teenagers think fighting is the embodiment of his ability affected by some violent film. This wrong thought must be found and corrected in a timely manner. On the other hand, the education method is based on the characteristics of adolescents' mental and physical growth, From middle school to university, each age teenagers have their own personality psychological needs, the content and the method of legal education should showed a certain level, so as to achieve the specific analysis of specific issues, to achieve a better education effect.

\subsection{Constructing the scientific and reasonable system of teenager legal education}

Youth legal education is not only the responsibility of school, but an important task for the social, school and family. "we need to build a system of teenager legal 
education should be made up of three-dimensional, continuous, and extensive education system, young people is the object of it, the community, schools and families is the main body, to form a legal education for all-round and multilevel based on the value ." [4] Therefore, society, school and family should act with united strength in order to improve the teenagers' legal literacy contribution. The society is responsible for the macro-grasp of the direction, the government must strengthen the relevant publicity of legal education, and continuously regulate cube source, for the unhealthy information that influenced teenagers, and we should avoid it timely. And add the contents of legal education into the cube source, make the full use of extensive and rapid propagation of the development to improve the legal system education efforts. Guiding people to learn legal, understand the law and abide by the law. Creating a good atmosphere for rule of law in the whole society firstly. The school should make clear the subject of education status, improve the legal system education curriculum content and the educational method, put the legal education into students' quality education. In family education, first of all, parents should fully realize the important role of legal education, play an important role of supervision at the same time .Finding the undesirable tendencies of adolescent students and correct it in time, ensure that they establish legal awareness.

\subsection{The educators should reverse the education idea and mode}

Educator is the people who affect the education's quality development directly, including school teachers, administrators, teachers, parents, family part-time teachers and so on, The school teacher is the subject and the represent of the educators, we think that the person undertakes the education on duty in the education activity can be called educator in the broad sense. Legal education is the education activities for people, so our education ideas and ways should also conform to the people's physical and mental development, so that, the education can be accepted by the students, and achieve certain aims of education at last. First of all, we should face the existing drawbacks of traditional education method, but do not abandon the traditional method completely. For example, in the treatment of "indoctrination", we should realize that the advanced thought never spontaneously formed in the human brain, we need to deliver the correct contents and values to the people, so that they can really understand what is true and beauty, what is false and evil. But this kind of transportation should not convey disregarding the educators' status, it is teaching them gradually in the premise of understanding the physical characteristics and requirements of educated. Secondly, using the influence of infection method draw lessons from the ideological and political education, this is a method which has a good effect in the ideological and political education," it is a method that educators make full use of the social environment factor and the educator's own creation education scene, to have an effect on educated, cultivating the ideological and moral by the subtle way, and make them improved and sublimated." ${ }^{[5]}$ Legal education should be a process of practice from the internalization to the behavior outside, the influence of infection method can arouse the educated emotional resonance easily, make them get the recognition and acceptance of the contents of legal education, this method has a significant effect in adolescents. In specific situations, to help they understand the law, practice law, it is really an efficient way of education.

\section{CONCLUSIONS}

Carrying out necessary legal education is a very important task to ensure the teenagers grow up in a healthy atmosphere in our country. No matter is the school, the family or society all should be applied legal education for teenagers, to play a necessary role in improving their legal literacy. Although the overall planning and promote legal education still exists some shortcomings in our country at present, we have realized the important role of juvenile legal education, and constantly improve their work style in combination of the actual situation. China is a developing country in the primary stage of socialism in the world, the current social problems are may unavoidable in the 
development, juvenile legal education has a long way to go, only the whole social work together, play together can we ensure the education content promote better. Assuring the adolescent thrive in healthy atmosphere, and contribute themselves into the cause of socialism with Chinese characteristics.

\section{Reference}

[1]Jin Wenxi.Strengthening the Legal Education is an Important Measure to Prevent the Teenagers from Crime[J]China Youth Study, p36,2010 (11).

[2]Chen Zhili. Improving the Legal Quality of Young Students, Lay the Foundation for Building a Socialist
Country Ruled by Law [J]. Issues on Juvenile Crimes and Delinquency, P.1, 2003, (1)

[3]Jiang Zemin. The Theory of Socialist Chinese Characteristics [M]. Beijing: Central Literature Publishing House, 2002.

[4]Yan Xinyang. The Construction of Juvenile Legal Education System [J].Issues on Juvenile Crimes and Delinquency, p.22, 2003 (9).

[5]Qiu Weiguang. The Principle of Ideological and Political Education [M]. Higher Education Press, 1999 edition. 